\title{
Tabaco e inflamación crónica: social y clínica
}

Navarro Rodríguez MC. Tabaco e inflamación crónica: social y clínica. An Med Interna (Madrid) 2006; 23: 1-2.

El tabaquismo está considerado en nuestro medio la primera causa de enfermedad y muerte evitable $(1,2)$. Desde hace muchos años las autoridades sanitarias y diferentes sectores de la sociedad buscan medidas para reducir su consumo, la verdad sea dicha, sin terminar de conseguirlo.

Los últimos datos de prevalencia de tabaquismo en España están en torno al $31 \%$ en la población mayor de 15 años (3), proporción aún superior a las existentes en otros países europeos como Suecia (20\%), Portugal (23,3\%), Reino Unido $(27 \%)$, Dinamarca $(27 \%)$, Italia $(27,5 \%)$ o los Países Bajos (27,5\%) (4). La recomendación de la Organización Mundial de la Salud (OMS) es reducir a menos del $20 \%$ el número de fumadores en cada país y aunque se aprecia una cierta tendencia al descenso del consumo de tabaco (5-7), la realidad es que estamos muy lejos de cumplir este objetivo.

Ahondando en esta ardua lucha, en junio de 2003, el gobierno español firmó el Convenio Marco para el Control del Tabaco de la Organización Mundial de la Salud (8) y recientemente publicó la Ley 28/2005, de 26 de diciembre, de medidas sanitarias frente al tabaquismo y reguladora de la venta, el suministro, el consumo y la publicidad de los productos del tabaco (9).

Aún es pronto para saber lo que ocurrirá en nuestro país, pero lo lógico sería pensar que esta nueva legislación contribuirá al descenso en el consumo de tabaco en nuestro país, de forma similar a lo ocurrido en Italia tras la entrada en vigor de una ley incluso más restrictiva, con fecha 1 de enero de 2005. Al cabo de tan solo un año, se observó un descenso de 500.000 fumadores (10).

La actual situación social de fumadores y no fumadores no debería generar una especie de guerra sin cuartel entre ambos grupos. Un principio filosófico elemental establece que la libertad de una persona acaba donde empieza la de otra. Todas estas medidas contra el tabaco no deben entenderse ni como un ataque al fumador, ni como una actitud paternalista demostrándole o imponiéndole lo que es bueno o malo. Debe entenderse tan solo como una cuestión de respeto hacia la voluntad del no fumador, obligado a convertirse hasta el momento en fumador pasivo. Por ejemplo, un no fumador, que trabaja en un restaurante donde se permita fumar, no tiene elección: o se convierte en un fumador pasivo (con las consecuencias que ello trae para su salud) o pierde su puesto de trabajo. Sin embargo a la inversa, el fumador cliente de ese mismo restaurante, puede levantarse en cualquier momento y salir al exterior y fumar cuanto le plazca.

Y si por una parte, la lucha contra el tabaquismo avanza, por otra también lo hace la ciencia conociendo mejor los mecanismos fisiopatológicos por los que el tabaco es perjudicial. Así, Martín de Diego y cols. (11) efectúan un estudio en una población de 762 varones aparentemente sanos, con una edad media de 41 años, en donde existen fumadores, exfumadores y no fumadores y determinan los niveles de proteína $\mathrm{C}$ reactiva $(\mathrm{PCR})$ por una técnica ultrasensible, observando que existe una elevación estadísticamente significativa de los niveles de esta proteína en los grupos de exfumadores y fumadores. De forma inequívoca, estos autores establecen que el aumento de la PCR guarda una relación directa con el número de cigarrillos al día, los miligramos de alquitrán y los miligramos de nicotina consumidos, así como con la duración del hábito tabáquico, siendo este último el factor más determinante.

Todo ello pone una vez más de manifiesto la asociación entre el consumo de tabaco y niveles de PCR indicativos de inflamación crónica, lo cual se sospechaba desde hace tiempo, incluso en fumadores pasivos, al observarse por ejemplo, en los niños que viven en un ambiente con padres fumadores, una mayor prevalencia de procesos inflamatorios e infecciosos de repetición, como otitis, rinitis y faringitis $(12,13)$. Sin embargo, hasta que punto el conocido efecto aterogénico es debido al proceso inflamatorio o a la coexistencia de una infección crónica como describieron en 2002 Kiechl y cols. (14) entre otro posibles factores, es un tema que queda aún por dilucidar. No cabe duda, que un mejor conocimiento fisiopatológico de la forma en que el tabaco produce el daño ayuda en la ardua lucha para erradicar el tabaquismo en nuestra sociedad. Y artículos como el actual, que demuestra que en una 
población de varones sanos ex-fumadores y fumadores existen datos bioquímicos que indican la existencia de una inflamación crónica y un aumento del riesgo cardiovascular, sin duda ayudan a ello.

\section{Bibliografía}

1. Banegas Banegas JR, Díez Gañán L, Rodríguez Artalejo F, González Enríquez J, Graciano Pérez-Regadera A, Villar Álvarez F. Mortalidad atribuible al tabaquismo en España en 1998. Med Clin (Barc) 2001; 117: 692-4.

2. González Enríquez J, Salvador Llivina T, López Nicolás A, Antón de las Heras E, Musín A, Fernández E, et al. Morbilidad, mortalidad y costes sanitarios evitables mediante una estrategia de tratamiento del tabaquismo en España. Gac Sanit 2002; 16 (4): 308-17.

3. Ministerio de Sanidad y Consumo. Encuesta Nacional de Salud 2003. Madrid, 2005.

4. Camarelles Guillem F. "Spain is different" en la prevención y control de tabaquismo. Aten Primaria 2004; 33: 481-2.

5. Ministerio de Sanidad y Consumo. Plan Nacional de Prevención de tabaquismo 2003.

6. Nebot M, Tomás Z, López MJ, Ariza C, Díez E, Borrell C, et al: Cambios en el consumo de tabaco en la población general en Barcelona, 1983-2000. Aten Primaria 2004; 34 (9): 457-64.

7. Camarelles Guillém F. Tendencias en el consumo de tabaco en España. Aten Primaria 2004; 34: 43-4.

8. OMS. Convenio Marco para el Control del Tabaco. Disponible en: www.who.int/gb/fctc/5/5_Index.htm. Consultada el 1 de febrero de 2006.

\section{C. NAVARRO RODRÍGUEZ}

Grupo de Investigación en Educación y Promoción de la

Salud. Universidad de Las Palmas de Gran Canaria.

Facultad de Ciencias de la Salud. Las Palmas de Gran

Canaria

9. Ley $28 / 2005$, de 26 de diciembre, de medidas sanitarias frente al tabaquismo y reguladora de la venta, el suministro, el consumo y la publicidad de los productos del tabaco. BOE n 309 , martes 27 de diciembre de 2005, 42241-50.

10. 500.000 italianos dejaron de fumar en e primer año de prohibición. En: tabaquismo. El mundo.es/salud. http: //www.elmundo.es/elmundosalud/2006/01/10/tabaco/1136895267.html. Consultado el 24 de enero de 2006.

11. Martín de Diego CE, Gómez de Terreros Sánchez FJ, Caro de Miguel MC, Medina Font J, Matesanz Ruiz C, Gómez de Terreros Caro J. Valor de la proteína $C$ reactiva según historia de tabaquismo y composición de nicotina y alquitrán. An Med Interna (Madrid) 2006; 23: 3-10.

12. Strachan DP, Jarvis MJ, Feyerabend C. Passive smoking, salivary cotinine concentrations, and middle ear effusion in 7 year old children. BMJ 1989; 298: 1549-52.

13. Shiva F, Nasiri M, Sadeghi B, Padyab M. Effects of passive smoking on common respiratory symptoms in young children. Acta Paediatr 2003; 92: 1394-7.

14. Kiechl S, Werner P, Egger G, Oberhollenzer F, Mayr M, Xu Q, et al: Active and Passive Smoking, Chronic Infections, and the Risk of Carotid Atherosclerosis: Prospective Results From the Bruneck Study Stroke $2002 ; 33 ; 2170-6$ 